\title{
Aqueous Hydricity of Late Metal Catalysts as a Continuum Tuned by Ligands and the Medium
}

\author{
Catherine L. Pitman, Kelsey R. Brereton, and Alexander J. M. Miller* \\ Department of Chemistry, University of North Carolina at Chapel Hill, Chapel Hill, North Carolina 27599-3290, United States
}

Supporting Information

ABSTRACT: Aqueous hydride transfer is a fundamental step in emerging alternative energy transformations such as $\mathrm{H}_{2}$ evolution and $\mathrm{CO}_{2}$ reduction. "Hydricity," the hydride donor ability of a species, is a key metric for understanding transition metal hydride reactivity, but comprehensive studies of aqueous hydricity are scarce. An extensive and self-consistent aqueous hydricity scale is constructed for a family of $\mathrm{Ru}$ and Ir hydrides that are key intermediates in aqueous catalysis. A reference hydricity is determined using redox potentiometry and spectrophotometric titration for a particularly water-soluble species. Then, relative hydricity values for a range of species are measured using hydride transfer equilibria, taking advantage of expedient new synthetic procedures for $\mathrm{Ru}$ and Ir hydrides. This large collection of hydricity values provides the most comprehensive picture so far of how ligands impact hydricity in water. Strikingly, we also find that hydricity can be viewed as a continuum in water: the free energy of hydride transfer changes with $\mathrm{pH}$, buffer composition, and salts present in solution.

\section{INTRODUCTION}

Aqueous hydride transfer is an essential process in enzymatic catalysis in nature, ${ }^{1,2}$ emerging fuel synthesis schemes for alternative energy, ${ }^{3-6}$ and biphasic catalysis in chemical industry. ${ }^{7,8}$ Hydrogenase enzymes, ${ }^{9,10}$ for example, can produce (or split) hydrogen with exceptional rates via transition metal hydride intermediates. ${ }^{1}$ Long-sought synthetic mimics that catalyze hydrogen evolution in aqueous solutions remain a pressing challenge. ${ }^{4,11}$ Further, in the petrochemical industry, an aqueous-phase $\mathrm{Rh}$ hydride produces $\sim 800000$ tons/year $n$ butyraldehyde for plastics. ${ }^{7}$ Understanding and predicting the reactivity of transition metal hydrides in water will continue to gain importance as alternative feedstocks such as biomass and $\mathrm{CO}_{2}$, which can be reduced using hydride complexes, become increasingly prevalent in the synthesis of chemicals and fuels. ${ }^{6}$

Thermochemical studies of metal hydrides provide a foundation for rational design of catalysts and for mechanistic studies of $2 \mathrm{e}^{-}$proton-coupled electron transfer (PCET) reactions. ${ }^{12,13}$ In acetonitrile, DuBois and Rakowski DuBois pioneered the determination of hydricity and its use as a powerful tool for reaction development in organic solvents. ${ }^{14-16}$ In one stunning example, a decade of thermochemistry-guided catalyst design culminated in a hydrogen evolution electrocatalyst that can operate faster than hydrogenase enzymes. $^{17,18}$

In light of the benefits that thermochemical understanding could have in the development of hydride-mediated catalysis in water, the aqueous hydricity of metal hydrides has been, until recently, surprisingly unexplored. ${ }^{19}$ Creutz and Chou's seminal early efforts relied on experimentally challenging approach-toequilibrium kinetics under $\mathrm{CO}_{2}{ }^{20,21}$ Recently, the groups of Yang and Berben each reported the hydricity of one metal hydride based on the thermodynamics of $\mathrm{H}_{2}$ cleavage reactions. $^{22,23}$ Our interest in a family of Cp*Ir-based catalysts ( $\mathrm{Cp} *$ is pentamethylcyclopentadienyl) motivated us to develop a general and expedient method for aqueous hydricity determination in this series of complexes.

Preliminary studies on the parent complex $[\mathrm{Cp} * \operatorname{Ir}(\mathrm{bpy})$ $(\mathrm{H})]^{+}\left(1 \mathrm{H}\right.$; bpy is $2,2^{\prime}$-bipyridine $)$ were stymied by the waterinsolubility of the conjugate base $C \mathrm{p}^{*} \operatorname{Ir}(\mathrm{bpy})(\mathbf{1}){ }^{24}$ so we charted a course utilizing carboxylate groups on the ligand to confer water solubility. We would first establish the hydricity of a reference complex using a potential $-\mathrm{p} K_{\mathrm{a}}$ thermochemical cycle in water (Figure 1A) and then map the relative hydricity of other complexes based on hydride transfer equilibria (Figure 1B). The potential-p $K_{\mathrm{a}}$ thermochemical cycle has been used extensively in acetonitrile, ${ }^{25}$ but has not been successfully applied in water.

The strategy depicted in Figure 1 has enabled the construction of an extensive, self-consistent aqueous hydricity scale. The broad range of Ir and Ru hydricity values reveals how the polar, protic aqueous environment impacts hydride transfer thermodynamics. Substantial shifts in the hydricity values are observed relative to acetonitrile, with electronic changes to the supporting ligand correlated strongly to the Hammett

Received: November 25, 2015

Published: January 17, 2016 


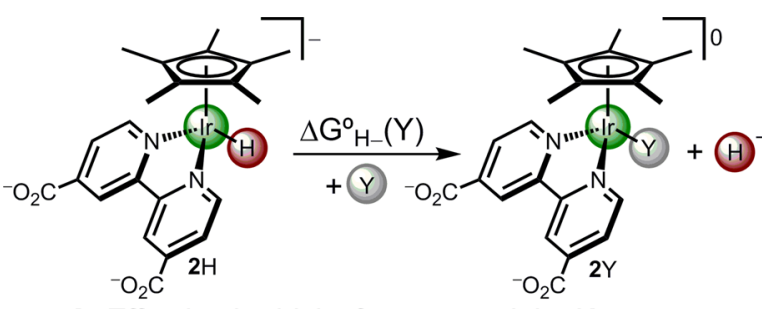

A. Effective hydricity from potential-pKa

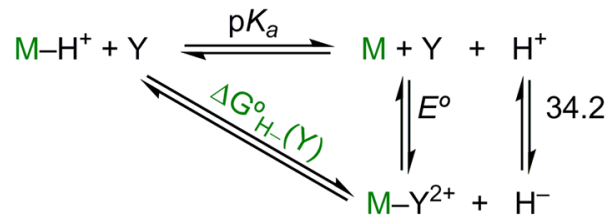

$\Delta \mathrm{G}^{\circ} \mathrm{H}_{-}(\mathrm{Y})=(1.364) \mathrm{pK} K_{a}-(-46.12) E^{\circ}+34.2 \mathrm{kcal} \cdot \mathrm{mol}^{-1}$

B. Relative hydricity from equilibrium

$$
\begin{aligned}
& \mathrm{M}-\mathrm{H}^{+}+\mathbf{M}^{\prime}-\mathbf{Y}^{+} \stackrel{K_{\text {eq }}\left(\Delta \Delta \mathrm{G}^{\circ} \mathrm{H}_{-}\right)}{\rightleftharpoons} \mathrm{M}-\mathrm{Y}^{+}+\mathbf{M}^{\prime}-\mathrm{H}^{+} \\
& \Delta \mathbf{G}^{\circ}{ }_{H-}(\mathrm{Y})=(1.364) p K_{e q}+\Delta \mathrm{G}^{\circ}{ }_{H_{-}}(\mathrm{Y})
\end{aligned}
$$

Figure 1. Scheme illustrating the hydricity of reference complex $\left[\mathrm{Cp}^{*} \operatorname{Ir}(\text { bpy-COO })(\mathrm{H})\right]^{-}(\mathbf{2 H})$ and thermochemical cycles that establish aqueous hydricity of Ir and Ru hydrides.

parameter $\sigma_{\mathrm{p}-}$. A dramatic impact of water was also observed in the primary coordination sphere: a variety of suitable ligands present in aqueous media can bind the Ir or Ru centers after hydride transfer, shifting the effective hydricity substantially. Describing the complexities of hydride transfer in water allows interpretation of previously reported catalytic reactions and predictions that can guide improvements in the hydrogenation of carboxylic acids, ${ }^{26}$ the disproportionation of formic acid to methanol, ${ }^{27}$ and other metal hydride-mediated reactions such as $\mathrm{H}_{2}$ evolution ${ }^{28-31}$ and $\mathrm{CO}_{2}$ reduction. ${ }^{28,32,33}$

\section{RESULTS AND DISCUSSION}

The first "reference" hydride investigated was $[\mathrm{Cp} * \operatorname{Ir}(\mathrm{bpy}-$ $\mathrm{COO})(\mathrm{H})]^{-}\left(2 \mathrm{H} ; \quad\right.$ bpy-X $=4,4^{\prime}$-X-bpy $)$, with carboxylate groups installed on the bipyridine ligand to confer good water solubility over a wide $\mathrm{pH}$ range, independent of metal ligation or oxidation state. ${ }^{34}$ The hydricity of $2 \mathrm{H}$ was targeted through the potential $-\mathrm{p} K_{a}$ thermochemical cycle of Figure $1 \mathrm{~A}$.

The reduction potential of $[\mathrm{Cp} * \operatorname{Ir}($ bpy-COOH $)(\mathrm{Cl})][\mathrm{Cl}]$ $(2 \mathrm{Cl})$ was initially assessed using cyclic voltammetry $(\mathrm{CV})$ in 1 $\mathrm{M} \mathrm{NaOH}$. Under these conditions, the chloride is displaced by hydroxide to form $\left[\mathrm{Cp}^{*} \operatorname{Ir}(\text { bpy-COO })(\mathrm{OH})\right]^{-}(2 \mathrm{OH})$ based on NMR and MS data, and a $2 \mathrm{e}^{-}$reduction forms the freely diffusing species $[\mathrm{Cp} * \operatorname{Ir}(\mathrm{bpy}-\mathrm{COO})]^{2-}(2)$. Unfortunately, a large peak-to-peak separation was observed between the reduction of $2 \mathrm{OH}$ and the oxidation of 2 (Figure S4). This electrochemical irreversibility, attributed to slow electron transfer or slow ligand dissociation, prevented the use of $\mathrm{CV}$ to determine $E_{1 / 2}$.

Biochemists have developed an electrochemical technique suitable for quantifying reduction potentials that are hampered by slow kinetics: redox potentiometry. ${ }^{35}$ Solutions varying the relative concentrations of $2 \mathrm{OH}$ and 2 were prepared by partial electrolysis of a $\mathrm{pH} 14$ solution of $2 \mathrm{OH}$ (Figure S7). Between each stage of the electrolysis, the solution was allowed to reach equilibrium (as judged by a constant open circuit potential) and the concentrations of the Ir species were determined by UVvis (Figure 2A). This method provided $E^{\circ \prime}=-0.60 \mathrm{~V}$ for the
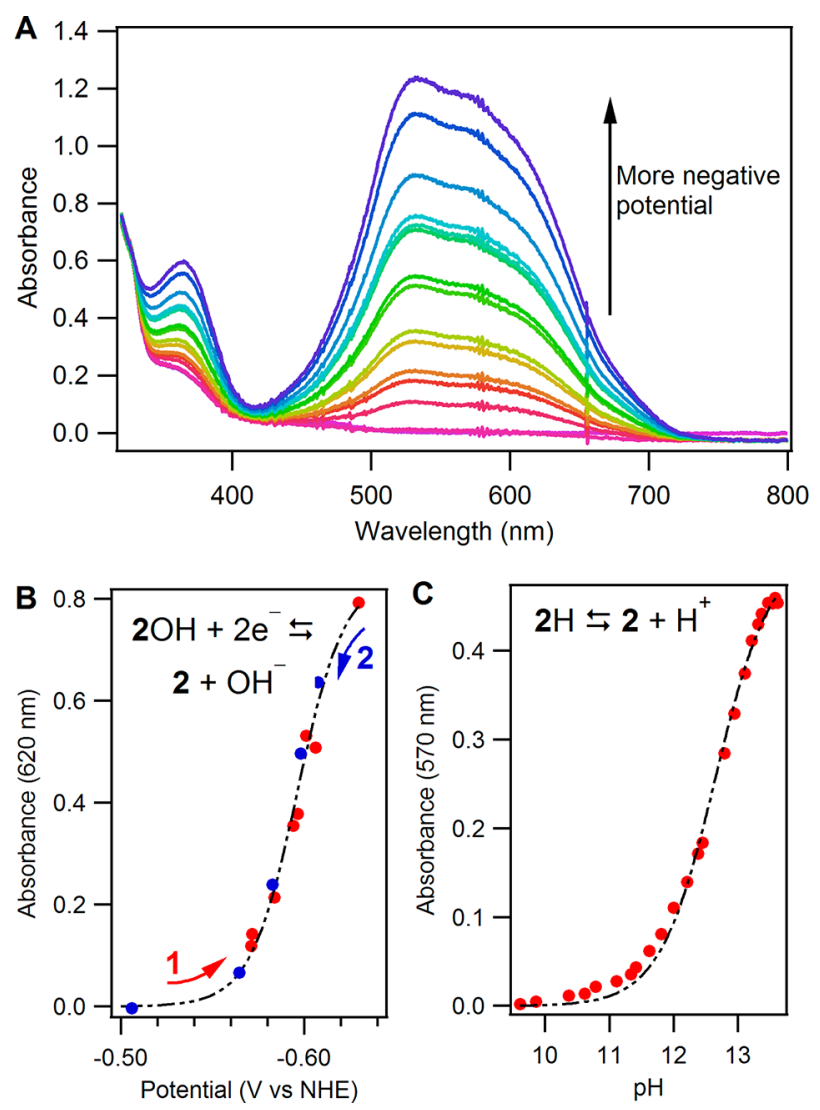

Figure 2. (A) Spectral changes of a $\mathrm{pH} 14$ solution of $[\mathrm{Cp} * \operatorname{Ir}(\mathrm{bpy}-$ $\mathrm{COO})(\mathrm{OH})]^{-}(2 \mathrm{OH})$ as the solution potential is decreased by electrolysis to form $[\mathrm{Cp} * \operatorname{Ir}(\text { bpy-COO })]^{2-}(2)$. (B) Absorbance at 620 $\mathrm{nm}$ stepping in the negative potential direction (red dots), the positive potential direction (blue dots), and the fit to the Nernst equation (dotdashed line) giving $E^{\circ \prime}=-0.60 \mathrm{~V}$. The lack of hysteresis indicates that equilibrium was established. (C) Absorbance at $570 \mathrm{~nm}$ of a $\mathrm{pH}$ titration of $\left[\mathrm{Cp}^{*} \operatorname{Ir}(\mathrm{bpy}-\mathrm{COO})(\mathrm{H})\right]^{-}(2 \mathrm{H})$ forming 2 (red dots) and the fit to the Henderson-Hasselbalch equation (dot-dashed line) giving $\mathrm{p} K_{\mathrm{a}}=12.4$.

reduction of $2 \mathrm{OH}$ to 2 at $\mathrm{pH} 14$ (Figure 2B). As thermodynamic constants for proton reduction are determined at the standard state of $\mathrm{pH} 0,{ }^{12,19}$ this reduction was extrapolated to $\mathrm{pH} 0$ by applying a $29.5 \mathrm{mV}$ per $\mathrm{pH}$ unit shift $\left(2 \mathrm{e}^{-}\right.$reduction with loss of hydroxide), giving $E^{\circ}=-0.19$ $\mathrm{V}$. Redox potentiometry is seldom used in organometallic chemistry, ${ }^{36-38}$ but this method was essential to overcoming the slow kinetics that prevented the straightforward measurement of thermodynamic values.

With a reduction potential in hand, hydricity could be determined if paired with the metal hydride $\mathrm{p} K_{\mathrm{a}}$ value. The water-soluble Ir complexes possess several acidic protons. Spectrophotometric titrations established the $\mathrm{p} K_{a}$ of the carboxylic acid groups in $\left[\mathrm{Cp} * \operatorname{Ir}(\mathrm{bpy}-\mathrm{COOH})\left(\mathrm{OH}_{2}\right)\right]^{2+}$ and $[\mathrm{Cp} * \operatorname{Ir}(\text { bpy-COOH })(\mathrm{H})]^{+}$as 1.9 and 2.7 , respectively. The acidity of $2 \mathrm{H}$ was then measured spectrophotometrically by addition of base to a yellow-orange solution of $2 \mathrm{H}$ to produce a deep purple solution of 2 (Figure $2 \mathrm{C}$ ), providing $\mathrm{pK}_{\mathrm{a}}(2 \mathrm{H})=$ 12.4. The relatively acidic carboxylic acid groups provide a doubly anionic supporting ligand at $\mathrm{pH} 7$ and ensure that hydride donation will not be coupled to protonation changes at the ligand.

$$
\mathbf{2} \mathrm{H} \leftrightarrows \mathbf{2}+\mathrm{H}^{+}
$$




$$
\begin{aligned}
& 2+\mathrm{OH}^{-} \leftrightarrows 2 \mathrm{OH}+2 \mathrm{e}^{-} \\
& \mathrm{H}^{+}+2 \mathrm{e}^{-} \leftrightarrows \mathrm{H}^{-} \\
& 2 \mathrm{H}+\mathrm{OH}^{-} \leftrightarrows 2 \mathrm{OH}+\mathrm{H}^{-}
\end{aligned}
$$

The hydricity of reference complex $2 \mathrm{H}$ was established by combining the $\mathrm{p} K_{a}$ of the metal hydride (eq 1 ), the oxidation potential of the conjugate base (eq 2), and the free energy of proton reduction to hydride (eq $\left.3,34.2 \mathrm{kcal} \cdot \mathrm{mol}^{-1}\right) .{ }^{19}$ This thermochemical cycle provides $\Delta G_{\mathrm{H}^{-}}^{\circ}(\mathrm{OH})=42.4 \mathrm{kcal} \cdot \mathrm{mol}^{-1}$ (eq 4), employing the conventional standard state of $\mathrm{pH} 0$.

The hydricity $\Delta G^{\circ} \mathrm{H}^{-}(\mathrm{OH})$ is the free energy of hydride transfer from $2 \mathrm{H}$ with formation of the hydroxo complex $2 \mathrm{OH}$. Hydroxide binding is involved in the experimentally measured reduction potential, so thermochemistry involving this ligand is obtained directly. The free energy of hydride transfer from $2 \mathrm{H}$ with formation of the aquo complex $2 \mathrm{OH}_{2}$ can also be determined by taking into account the $\mathrm{p} K_{\mathrm{a}}$ of $2 \mathrm{OH}_{2}$ (eq 5, pK $=7.6$ by spectrophotometric titration $): \Delta G_{\mathrm{H}^{-}}^{\circ}\left(\mathrm{OH}_{2}\right)=32.0$ $\mathrm{kcal} \cdot \mathrm{mol}^{-1}$.

$$
\mathbf{2 O H}+\mathrm{H}^{+} \leftrightarrows \mathbf{2} \mathrm{OH}_{2}
$$

An unusual situation arises when taking into account the metal aquo acidity: there are two different hydricity values for $2 \mathrm{H}, \Delta G^{\circ} \mathrm{H}^{-}(\mathrm{OH})$ and $\Delta G^{\circ}{ }_{\mathrm{H}^{-}}\left(\mathrm{OH}_{2}\right)$. Formal hydride transfer initially results in a $16 \mathrm{e}^{-}$complex with a vacant coordination site, and this hydride dissociation process $\left(\Delta G_{\mathrm{H}^{-}}\right.$in Scheme 1)

\section{Scheme 1}

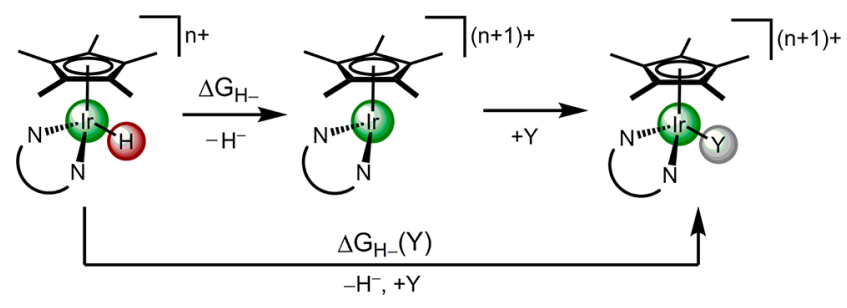

is most commonly associated with hydricity. In many cases, however, the coordinatively unsaturated complex rapidly binds a ligand (e.g., solvent or a counterion) during the net hydride transfer process. In organic solvents, solvation of the metal center after hydride transfer is commonly ignored in the thermochemistry: the activity of the solvent is taken as unity. ${ }^{39-42}$ Water inherently contains hydroxide ions capable of binding the metal center, leading to a distinct (and $\mathrm{pH}$ dependent) hydricity value.

The obtained thermodynamic values $\Delta G_{\mathrm{H}^{-}}^{\circ}(\mathrm{OH})$ and $\Delta G^{\circ}{ }^{-}\left(\mathrm{OH}_{2}\right)$ include the formal hydricity and the binding affinity for the incoming ligand (Scheme 1). A similar situation arises for acidities when, following proton loss, aggregation through hydrogen-bonding interactions (e.g., homoconjugation) influences effective acidity. ${ }^{43}$ To distinguish the different effective hydricity values that couple hydride transfer and ligand association, the nomenclature $\Delta G^{\circ} \mathrm{H}^{-}(\mathrm{Y})$ is used, where $\mathrm{Y}$ is the incoming ligand.

Aqueous catalysis is typically carried out in the presence of various buffers and salts, and these species can also alter hydricity through metal ligation. To better understand the role of incoming ligands, we explored the effect of phosphate and chloride on hydricity. Effective hydricity values were determined by measuring the free energy of ligand exchange with $2 \mathrm{OH}_{2}$ (Figure 3A) and adding that thermodynamic value
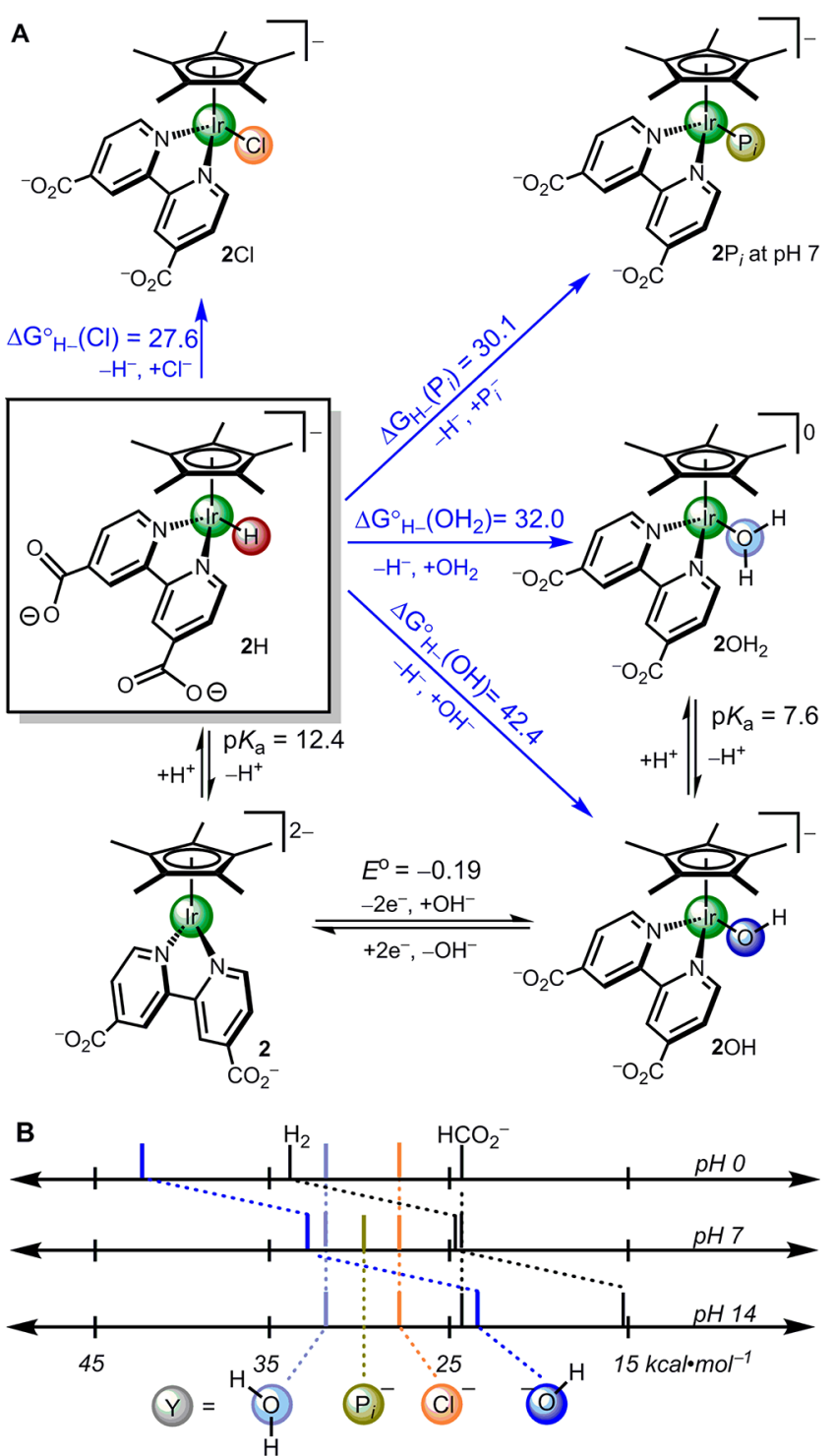

Figure 3. (A) Summary of thermochemical values of $[\mathrm{Cp} * \operatorname{Ir}(\mathrm{bpy}-$ $\mathrm{COO})(\mathrm{H})]^{-}(2 \mathrm{H})$. Free energies $\left(\mathrm{kcal} \cdot \mathrm{mol}^{-1}\right)$ and reduction potentials (V vs NHE) are cited at the standard state of $\mathrm{pH} 0,1 \mathrm{M}$ reagents, and 1 atm gases, except for $\Delta G_{\mathrm{H}^{-}}\left(\mathrm{P}_{i}\right)$ that refers to $\mathrm{pH}$ 7. (B) Summary of the $\mathrm{pH}$ dependence of $\Delta G_{\mathrm{H}}-(\mathrm{Y})$ with the $\mathrm{H}_{2} \mathrm{O} / \mathrm{H}_{2}$ and $\mathrm{CO}_{2} / \mathrm{HCO}_{2}{ }^{-}$couples.

to $\Delta G^{\circ}{ }_{H^{-}}\left(\mathrm{OH}_{2}\right)$. The relative free energy of chloride substitution was determined by $\mathrm{NMR}$ titration of $\mathrm{NaCl}$ into a pD 7 solution of $2 \mathrm{OH}_{2}, \Delta G_{\mathrm{OH}_{2} \rightarrow \mathrm{Cl}}=-4.4 \mathrm{kcal} \cdot \mathrm{mol}^{-1}$ (eq 6). Because ligand exchange is slow on the NMR time scale, the concentrations of the iridium species could be determined directly. The hydricity of $2 \mathrm{H}$ to form the chloride product is thus $\Delta G^{\circ}{ }_{\mathrm{H}^{-}}(\mathrm{Cl})=27.6 \mathrm{kcal} \cdot \mathrm{mol}^{-1}$ (Figure $\left.3 \mathrm{~A}\right)$.

$$
\begin{aligned}
& \mathbf{2} \mathrm{OH}_{2}+\mathrm{Cl}^{-} \leftrightarrows \mathbf{2} \mathrm{Cl}+\mathrm{H}_{2} \mathrm{O} \\
& \mathbf{2} \mathrm{OH}_{2}+\mathrm{P}_{i}^{-} \leftrightarrows \mathbf{2} \mathrm{P}_{i}+\mathrm{H}_{2} \mathrm{O}
\end{aligned}
$$

The phosphate buffer presents both $\mathrm{H}_{2} \mathrm{PO}_{4}{ }^{-}$and $\mathrm{HPO}_{4}{ }^{2-}$ ligands at $\mathrm{pH} 7$, either of which can bind $\mathrm{Ir}(\mathrm{III}) .^{30}$ Phosphate binding is apparent by NMR spectroscopy in $\mathrm{pH} 7$ phosphate buffer, but rapid proton exchange prevents precise identification of the ligand protonation state. The relative binding affinity of the phosphate mixture $\left(\Delta G_{\mathrm{OH}_{2} \rightarrow \mathrm{P}_{i}}=-1.9 \mathrm{kcal} \cdot \mathrm{mol}^{-1}\right.$ at $\mathrm{pH} 7$, 
eq 7) provides $\Delta G_{\mathrm{H}^{-}}\left(\mathrm{P}_{\mathrm{i}}\right)=30.1 \mathrm{kcal} \cdot \mathrm{mol}^{-1}$. This hydricity is strictly accurate only at $\mathrm{pH} 7$, where the measurement was made for the specific $\mathrm{H}_{2} \mathrm{PO}_{4}{ }^{-} / \mathrm{HPO}_{4}{ }^{2-}$ mixture which $\mathrm{P}_{i}^{-}$ represents. The concentrations of $\mathrm{H}_{2} \mathrm{PO}_{4}{ }^{-}$and $\mathrm{HPO}_{4}{ }^{2-}$ will change based on the solution $\mathrm{pH}$, however, which could impact hydride transfer.

Complex $2 \mathrm{H}$ is substantially more hydridic in water (smaller $\Delta G^{\circ}{ }^{-}\left(\mathrm{OH}_{2}\right)$ value) than in acetonitrile, consistent with prior studies. $^{22,23,41}$ The large differences in hydricity as a function of the ligands present in aqueous solution, however, were previously unexplored and suggest that water plays a role in hydride transfer reactions beyond simply providing a high polarity medium. Transition metal hydride transfer can be described by a manifold of hydricity values comprised of the heterolytic $\mathrm{M}-\mathrm{H}$ bond strength (to release $\mathrm{H}^{-}$) and the dative metal-ligand bond strength of any aqueous buffer components or salts.

The effective hydricity, $\Delta G_{\mathrm{H}^{-}}^{\circ}(\mathrm{Y})$, is expected to be experimentally relevant to catalysis. Hydride transfer reactions for $\mathrm{d}^{6}$ hydrides during catalysis will involve ligand association, so understanding the overall thermodynamics of that process is vital. ${ }^{44}$ For example, in a typical $\mathrm{pH} 7$ phosphate buffer solution used in photoelectrocatalytic $\mathrm{H}_{2}$ evolution, ${ }^{30}$ hydride $2 \mathrm{H}$ reacts with water to release $\mathrm{H}_{2}$ and generate an equilibrium mixture of Ir(III) chloride, aquo, and phosphate complexes - representing three different $\mathrm{H}_{2}$ release pathways with three different hydricity values.

In water, $\mathrm{pH}$ also becomes an integral factor in hydricity (Figure 3B). For one, the $\mathrm{H}_{2} \mathrm{O} / \mathrm{H}_{2}$ potential will shift to lower values as $\mathrm{pH}$ increases $\left(1.36 \mathrm{kcal} \cdot \mathrm{mol}^{-1} \cdot \mathrm{pH}^{-1}\right)$, indicating that as protons become scarcer, stronger hydrides are required to evolve $\mathrm{H}_{2}$. Yet while $\mathrm{H}_{2}$ is shifting, $\Delta G_{\mathrm{H}^{-}}^{\circ}(\mathrm{Cl})$ and $\Delta G^{\circ}{ }^{-}\left(\mathrm{OH}_{2}\right)$ remain constant across the accessible $\mathrm{pH}$ range, altering net $\mathrm{H}_{2}$ release thermodynamics. On the other hand, $\Delta G_{\mathrm{H}^{-}}(\mathrm{OH})$ is influenced by $\mathrm{pH}$ as the concentration of ligand available for binding changes with $\mathrm{pH}$. At $\mathrm{pH} 0$, hydroxide ligation is unfavorable, leading to $\Delta G^{\circ} \mathrm{H}^{-}(\mathrm{OH})>\Delta G^{\circ} \mathrm{H}^{-}\left(\mathrm{OH}_{2}\right)$; while chemical intuition might suggest that hydride transfer to form an aquo complex would be a less favorable than hydride transfer to form a complex with the more basic hydroxide ion, the extremely low concentration of hydroxide at $\mathrm{pH} 0$ leads to unfavorable energetics. As the solution $\mathrm{pH}$ increases, however, formation of the hydroxide complex will become more favorable, and the value $\Delta G_{\mathrm{H}^{-}}(\mathrm{OH})$ will shift smoothly. Figure $3 \mathrm{~B}$ illustrates that at $\mathrm{pH} 14, \Delta G_{\mathrm{H}^{-}}(\mathrm{OH})<\Delta G_{\mathrm{H}^{-}}\left(\mathrm{OH}_{2}\right)$ and complex $2 \mathrm{H}$ becomes a much stronger hydride donor.

Though the differences caused by incoming ligands in the aqueous medium are striking, their impact is best assessed by comparison to the effect of changing the metal center and supporting ligands. Modification of the structure of the hydride is the most common route to tune hydricity, and these synthetic strategies are typically assumed to have a greater influence than solvation of the product. To make these comparisons, we sought to explore a wider range of metal complexes and began by determining the hydricity of another soluble "reference" hydride, $[(\text { cymene }) \mathrm{Ru}(\text { bpy-COO })(\mathrm{H})]^{-}$ $(3 \mathrm{H})$. Hydride $3 \mathrm{H}$ hails from a family of (arene) $\mathrm{Ru}$ (diimine) catalysts that carry out aqueous transfer hydrogenation, water splitting, and $\mathrm{CO}_{2}$ reduction. ${ }^{32,45,46}$

The reduction potential of $[(\text { cymene }) \mathrm{Ru}(\mathrm{bpy}-\mathrm{COO})(\mathrm{OH})]^{-}$ $(3 \mathrm{OH})$ between $\mathrm{pH} 8$ and 12 was measured by CV. The quasireversible $3 \mathrm{OH} / 3$ couple $\left(\Delta E_{\mathrm{p}}=60 \mathrm{mV}\right)$ shifted $26 \mathrm{mV}$ per $\mathrm{pH}$ unit, close to the ideal value of $29.5 \mathrm{mV}$ expected for a
$1 \mathrm{OH}^{-} / 2 \mathrm{e}^{-}$process (Figure S20). Extrapolating the trend in $E_{1 / 2}$ to $\mathrm{pH} 0$ provided the standard reduction potential $E^{\circ}=$ $-0.30 \mathrm{~V}^{24}$

Spectrophotometric titrations provided the acidity of the hydride $3 \mathrm{H}, \mathrm{p} K_{a}=11.8$. From the $\mathrm{p} K_{\mathrm{a}}$ and $E^{\circ}, \Delta G^{\circ}{ }_{\mathrm{H}^{-}}(\mathrm{OH})=$ $36.5 \mathrm{kcal} \cdot \mathrm{mol}^{-1}$ can be determined. Including the aquo $\mathrm{pK} K_{\mathrm{a}}=$ 7.7 gives $\Delta G_{\mathrm{H}^{-}}^{\circ}\left(\mathrm{OH}_{2}\right)=26.0 \mathrm{kcal} \cdot \mathrm{mol}^{-1}$. (All the relevant $\mathrm{p} K_{\mathrm{a}}$ and $\Delta G_{\mathrm{H}^{-}}^{\circ}$ values for this system are collected in Table S1.) The relative aquo-chloride association free energy, $\Delta G_{\mathrm{OH}_{2} \rightarrow \mathrm{Cl}}$ $=-2.9 \mathrm{kcal} \cdot \mathrm{mol}^{-1}$, was significantly smaller than that of the Ir complex. Taken together, the hydricity to form the chloride was determined to be $\Delta G^{\circ} \mathrm{H}^{-}(\mathrm{Cl})=23.1 \mathrm{kcal} \cdot \mathrm{mol}^{-1}$.

Having established two well-defined reference hydricity values, we set out to determine the hydricity of related hydrides, including the parent bpy complexes. To probe hydride transfer equilibria between $\mathrm{Ir}$ and $\mathrm{Ru}$ hydrides, however, a reliable synthetic route to these species was required. Chloride counterions were sought to increase water solubility (the previously reported $\mathrm{PF}_{6}{ }^{-}$and $\mathrm{CF}_{3} \mathrm{SO}_{3}{ }^{-}$salts of $1 \mathrm{H}$ were insoluble above $2 \mathrm{mM}$ in water $)^{47}$ and to reduce speciation.

Electrochemical and chemical synthetic methods were developed to provide rapid access to a wide range of watersoluble metal hydrides. In a representative controlled potential electrolysis, the chloride salt of $1 \mathrm{Cl}$ was converted to $>20 \mathrm{mM}$ of $1 \mathrm{H}$ in $0.1 \mathrm{M} \mathrm{pH} 7 \mathrm{NaP}_{i}$. If the $\mathrm{pH}$ and electrolysis potential were appropriately controlled to facilitate a reductionprotonation sequence, the electrolysis method was quite general, as detailed in the Supporting Information (p. S20). Chemical syntheses were also carried out, as needed, according to a newly developed procedure. For example, reduction of the chloride salt of $1 \mathrm{Cl}$ by $\mathrm{NaBH}_{4}$ in $1 \mathrm{M} \mathrm{NaOH}$ resulted in precipitation of purple $\mathbf{1}$ in nearly quantitative yield. Dropwise addition of $\mathrm{HCl} \cdot \mathrm{Et}_{2} \mathrm{O}$ to a stirring solution of $\mathbf{1}$ in $\mathrm{Et}_{2} \mathrm{O}$ prompted precipitation of the golden yellow chloride salt of hydride $1 \mathrm{H}$. This procedure is also generally applicable, except when the metal hydride cannot be deprotonated in water or the conjugate base does not precipitate from water (see Supporting Information p. S20 for full details).

With a collection of hydride complexes (see Figure 4 for numbering scheme), relative hydricity could be determined by mixing a hydride donor and a hydride acceptor and allowing the system to reach an equilibrium distribution of both hydrides and acceptors. The concentration of each species was determined by NMR, and the equilibrium constant provided the difference in hydricity $\left(\Delta \Delta G^{\circ}{ }_{\mathrm{H}^{-}}\right)$between the two complexes, according to Figure $1 \mathrm{~B} .{ }^{48}$ Figure 4 depicts the relative hydricity of each hydride complex, with each reaction representing a hydride-chloride exchange.

In a representative hydride equilibration, a solution of $2 \mathrm{Cl}$ in pD $70.1 \mathrm{M} \mathrm{NaP}_{i}$ (produced electrochemically in $84 \%$ yield, with $16 \%$ unreacted $2 \mathrm{Cl}$ ) was mixed with $1 \mathrm{Cl}$. After the reaction was allowed to reach equilibrium, the concentrations of $1 \mathrm{H}, 1 \mathrm{Cl}, 2 \mathrm{H}$, and $2 \mathrm{Cl}$ were measured by ${ }^{1} \mathrm{H}$ NMR spectroscopy. The equilibrium constant, $K_{\mathrm{eq}}=0.35$, provided $\Delta \Delta G_{\mathrm{H}^{-}}^{\circ}=0.6 \mathrm{kcal} \cdot \mathrm{mol}^{-1}$ (eq 8 ) and established the hydricity of $1 \mathrm{H}$ in a single experiment: $\Delta G^{\circ} \mathrm{H}^{-}(\mathrm{Cl})=27.0 \mathrm{kcal} \cdot \mathrm{mol}^{-1}$. It is noteworthy that equilibration was established in $<15 \mathrm{~min}$, and though our present focus is on thermodynamic hydricity, this contrasts with the frequently kinetically slow hydride transfer reactions reported in acetonitrile. ${ }^{41,48}$

$$
2 \mathrm{H}+1 \mathrm{Cl} \leftrightarrows 2 \mathrm{Cl}+\mathbf{1 H}
$$




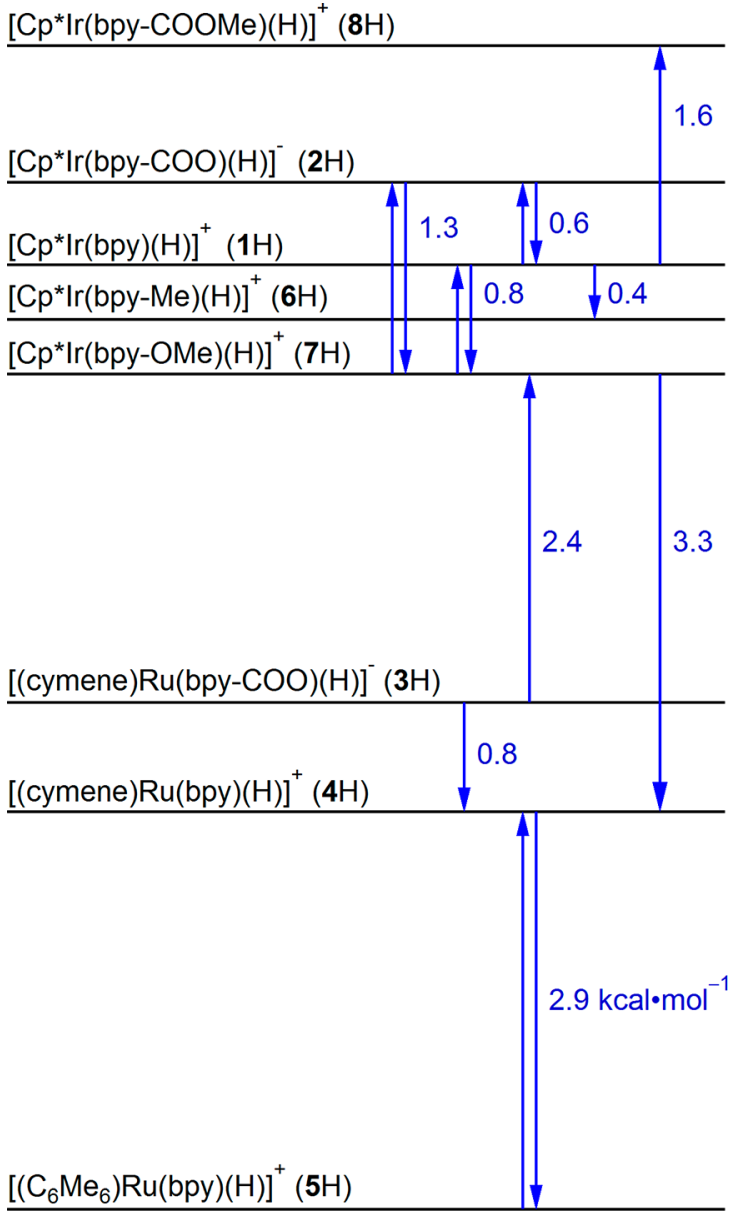

Figure 4. Relative hydricity values of Ir and Ru complexes (blue). The equilibria used to determine hydricity are represented by blue arrows.

A series of hydride transfer equilibrium experiments established the relative hydricity scale of Figure 4. Equilibrium could be established from either direction to give $\Delta \Delta G^{\circ}{ }_{\mathrm{H}^{-}}$ values that were identical within experimental uncertainty $\left( \pm 0.1 \mathrm{kcal} \cdot \mathrm{mol}^{-1}\right.$, see Supporting Information p. S36 for full experimental details). Hydricity values were determined from these relative hydricities by comparison to the $\Delta G^{\circ}{ }^{-}(\mathrm{Cl})$ of reference $2 \mathrm{H}$ for $\mathrm{Ir}$ complexes and reference $3 \mathrm{H}$ for $\mathrm{Ru}$ complexes, and the scale is self-consistent within the $\pm 1 \mathrm{kcal}$. $\mathrm{mol}^{-1}$ estimated uncertainty of the measurements. ${ }^{25,48,50}$ The $\Delta G^{\circ}{ }^{-}\left(\mathrm{OH}_{2}\right)$ for all complexes was determined by measuring the aquo-chloride relative association energy of each of these species (Table 1).

Table 1. Aquo-Chloride Association Free Energy and Hydricity to Form Ligated Products in $\mathrm{kcal} \cdot \mathrm{mol}^{-1}$

$\begin{array}{cccc}\text { complex } & \Delta G_{\mathrm{H}^{-}}^{\circ}(\mathrm{Cl}) & \Delta G_{\mathrm{H}^{-}}^{\circ}\left(\mathrm{OH}_{2}\right) & \Delta G_{\mathrm{OH}_{2} \rightarrow \mathrm{Cl}} \\ \mathbf{1} & 27.0 & 31.5 & -4.5 \\ \mathbf{2} & 27.6 & 32.0 & -4.4 \\ \mathbf{3} & 23.1 & 26.0 & -2.9 \\ \mathbf{4} & 22.3 & 25.6 & -3.3 \\ \mathbf{5} & 19.4 & 22.9 & -3.5 \\ \mathbf{6} & 26.6 & 31.1 & -4.5 \\ 7 & 26.2 & 30.8 & -4.6 \\ \mathbf{8} & 28.6 & 33.4 & -4.7\end{array}$

Our values are also consistent with one of the few other welldefined hydricity values available in the literature: the hydricity of $\left[\left(\mathrm{C}_{6} \mathrm{Me}_{6}\right) \mathrm{Ru}(\mathrm{bpy})(\mathrm{H})\right]^{+}(5 \mathrm{H})$ with formation of $5 \mathrm{OH}_{2}$ was reported by Creutz, $\Delta G^{\circ} \mathrm{H}^{-}\left(\mathrm{OH}_{2}\right)=22.2 \mathrm{kcal} \cdot \mathrm{mol}^{-1}$, ${ }^{19,21}$ which we independently determined to be $\Delta G^{\circ}{ }_{H^{-}}\left(\mathrm{OH}_{2}\right)=22.9 \mathrm{kcal}$. $\mathrm{mol}^{-1}$.

In Figure 5, our continuum of hydricity values is contextualized against previously reported hydricity values $\left(\Delta G_{\mathrm{H}^{-}}^{\circ}\left(\mathrm{OH}_{2}\right)\right)$ for transition metal hydrides and substrates relevant to alternative energy pursuits $\left(\mathrm{H}^{+}\right.$and $\left.\mathrm{CO}_{2}\right)$. The previously reported $\mathrm{Ru}$ and $\mathrm{Rh}$ complexes are aquated after hydride transfer. The two parallel scales illustrate the role of the ligand bound to the product and the influence of changes to the supporting ligands or metal center. In general, the hydricity values are much smaller in water than in acetonitrile. ${ }^{41,47}$

Electron-donating groups promote hydride transfer, as evidenced by a strong correlation between $\Delta G^{\circ} \mathrm{H}^{-}(\mathrm{Cl})$ and the Hammett parameter $\sigma_{\mathrm{p}-}$ (Figure 6). ${ }^{51}$ The $\mathrm{Ir}$ and $\mathrm{Ru}$ catalysts investigated herein become better hydride donors (lower $\Delta G^{\circ}{ }_{\mathrm{H}^{-}}$) with increasing electron density. Hydricity is moderated by electronic effects: increasing electron density increases $\mathrm{p} K_{\mathrm{a}}$ and shifts $E^{\circ}$ more negative which raise and lower hydricity, respectively. In fact, other systems have been found to be more influenced by the ligand bite angle than by electronics. $^{25}$ The ease with which each ligand can stabilize increased electron density is reflected in electronic spectroscopy: hydricity is correlated to the metal-to-ligand charge-transfer band around $400 \mathrm{~nm}$ that is present in each of the Ir hydride complexes (Figure S42). Interestingly, the activity of aqueous hydrogen evolution catalysis involving $\mathrm{Cp}$ *Ir-based catalysts also correlates with electron-donating ability of the bipyridine ligand, ${ }^{31}$ suggesting that perhaps the increase in rate is due to an increase in the hydricity of the metal hydride intermediate.

Electronic changes to the bipyridine ligands affect the acidity of the metal hydride more dramatically than the hydricity. The hydricity difference between methoxy-substituted $7 \mathrm{H}\left(\mathrm{pK}_{\mathrm{a}}>\right.$ 14) and methylester-substituted $8 \mathrm{H}\left(\mathrm{p} K_{\mathrm{a}} \sim 5\right.$, estimated from $\mathrm{CV}$, see Supporting Information p. S4) is only $2.4 \mathrm{kcal} \cdot \mathrm{mol}^{-1}$, while the acidity difference between these complexes spans $\sim 9$ orders of magnitude $\left(\sim 12 \mathrm{kcal} \cdot \mathrm{mol}^{-1}\right)$.

Ligand effects on hydricity were more pronounced when changes were made to the arene rings. ${ }^{48}$ Cymene complex $4 \mathrm{H}$ and hexamethylbenzene complex $5 \mathrm{H}$ displayed a $\sim 3 \mathrm{kcal} \cdot \mathrm{mol}^{-1}$ difference in hydricity that is larger than observed for bpy ligand modifications, but of a similar magnitude to the effect of chloride ligation. These differences warrant further studies into possible steric effects in these thermodynamic hydricity values.

The emerging picture of aqueous hydricity tunable by both ligands and the medium could impact catalysis. Electrocatalytic hydrogen evolution in water is usually carried out with $\mathrm{pH}$ stabilizing buffer bases, ${ }^{4}$ and water splitting schemes that employ salt water must wrestle with an abundance of chloride, ${ }^{52,53}$ which would lead to a $\sim 5 \mathrm{kcal} \cdot \mathrm{mol}^{-1}$ difference in the hydricity of Ir catalysts. The hydricity trends in Figure 5 also predict the $\mathrm{pH}$ at which $\mathrm{H}_{2}$ evolution will occur, as a function of the ligand electronics and the presence of incoming ligands in solution. All of the complexes investigated, for example, are predicted to produce $\mathrm{H}_{2}$ at $\mathrm{pH} 0\left(\Delta G_{\mathrm{H}^{-}}^{\circ}<34.2\right.$ $\left.\mathrm{kcal} \cdot \mathrm{mol}^{-1}\right)$, but at $\mathrm{pH} 10$ only $\mathrm{Ru}$ complex $5 \mathrm{H}$ is thermodynamically capable of forming $\mathrm{H}_{2}$ (and only at high chloride concentration). Under basic conditions, hydroxide ligation could also start to impact hydride transfer reactivity. 


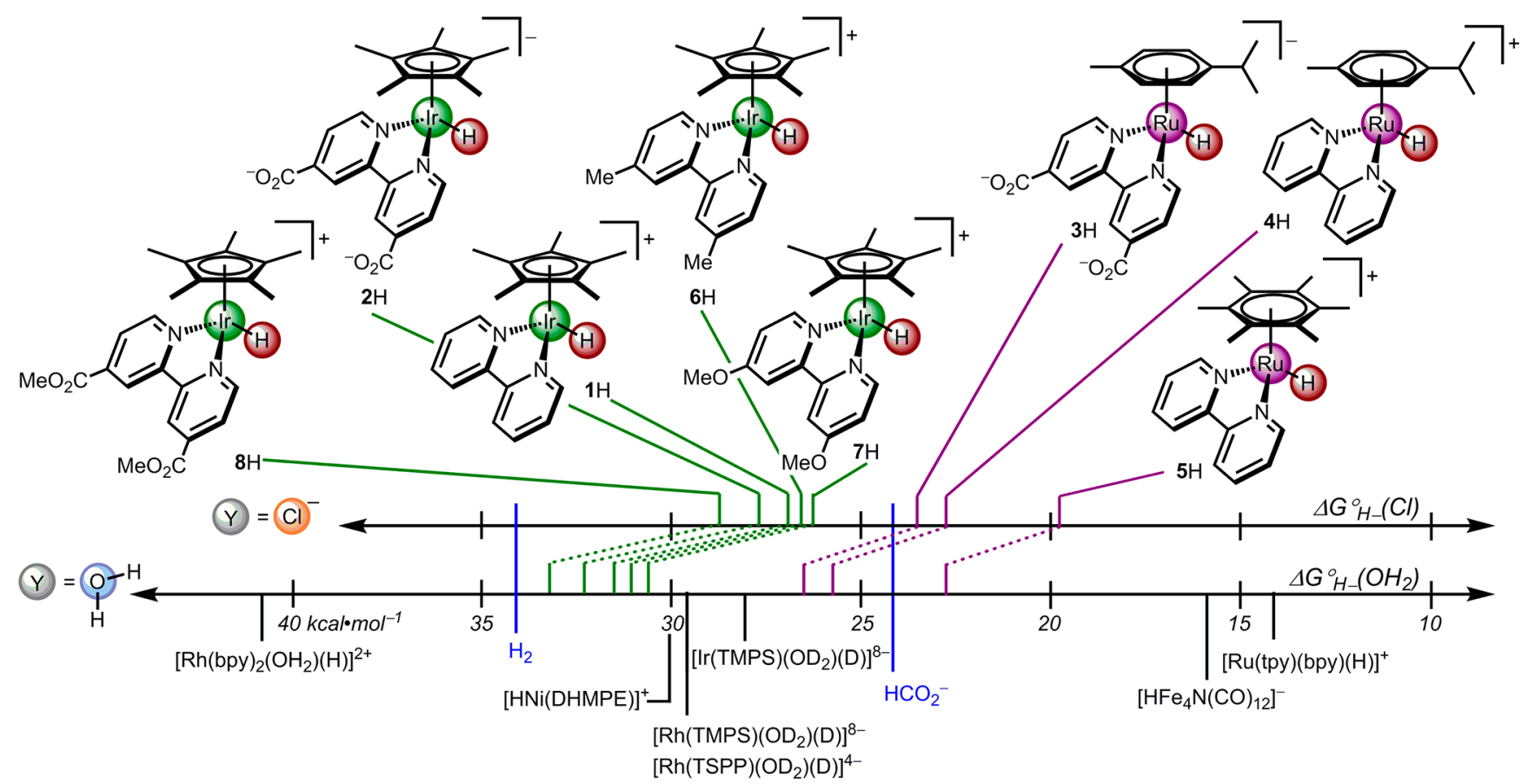

Figure 5. Aqueous hydricity scale of the complexes we report along with those previously reported in the literature. $\mathrm{Y}$ represents the incoming ligand such that the top scale shows $\Delta G_{H^{-}}^{\circ}(\mathrm{Cl})$ and the bottom scale shows $\Delta G^{\circ}{ }_{H^{-}}\left(\mathrm{OH}_{2}\right)$. TSPP $=\operatorname{tetra}(p$-sulfonatophenyl $)$ porphyrin; TMPS $=$ tetrakis(3,5-disulfonatomesityl)porphyrin; tpy = terpyridine; DHMPE = 1,2-bis(dihydroxymethylphosphino) ethane. ${ }^{19,22,23,49}$

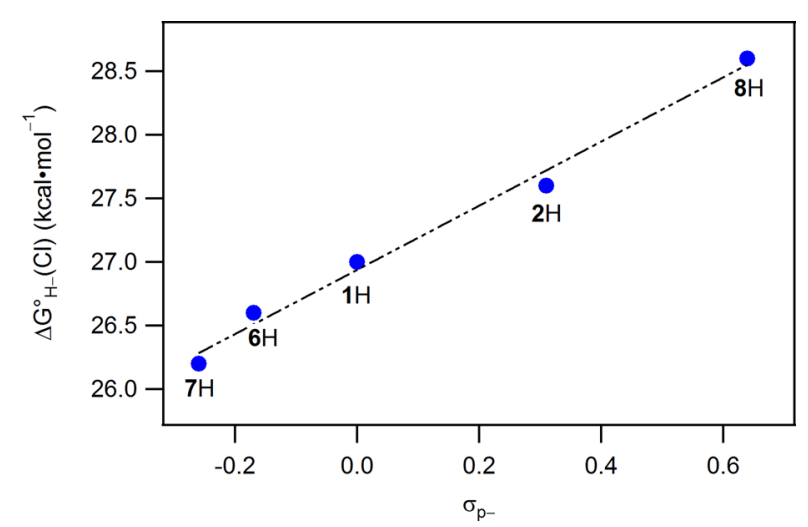

Figure 6. Correlation between $\sigma_{\mathrm{p}}^{-}$and $\Delta G^{\circ}{ }_{\mathrm{H}^{-}}(\mathrm{Cl})$.

The ability of a hydride to reduce $\mathrm{CO}_{2}$ to formate at $\mathrm{pH} 0$ can also be predicted by inspection of Figure 5. Species more hydridic than formate $\left(\Delta G_{\mathrm{H}^{-}}^{\circ}<24.1 \mathrm{kcal} \cdot \mathrm{mol}^{-1}\right)$ are thermodynamically capable of $\mathrm{CO}_{2}$ reduction. An intriguing prediction arises from Figure 5: $\mathrm{CO}_{2}$ reduction by hydride transfer from (cymene) $\mathrm{Ru}$ complexes $3 \mathrm{H}$ and $4 \mathrm{H}$ should be unfavorable in unbuffered water and favorable only when chloride anion is present. The less hydritic hydrides would require increased $\mathrm{CO}_{2}$ pressure to enable hydride transfer to $\mathrm{CO}_{2}$. In a prior report of $\mathrm{CO}_{2}$ hydrogenation, the Ir hydride $1 \mathrm{H}$ underwent slow, rate-limiting hydride transfer to $\mathrm{CO}_{2}$, while the $\mathrm{Ru}$ hydride $5 \mathrm{H}$ transferred hydride sufficiently quickly that $\mathrm{H}_{2}$ cleavage became rate-limiting. ${ }^{32}$ Our studies show that $5 \mathrm{H}$ is more hydridic than the parent $\mathrm{Ir}$ complex $1 \mathrm{H}$; the hydricity scale correctly predicts that $5 \mathrm{H}$ will more readily hydrogenate $\mathrm{CO}_{2}$ (and less readily cleave $\mathrm{H}_{2}$ ).

\section{CONCLUSIONS}

A general strategy for the determination of hydricity in water is presented. Comparisons across a range of well-known catalytic intermediates were enabled by an electrochemical technique well suited to the complications of water and by new synthetic routes to water-soluble hydrides. Thermodynamic hydricity in water is not only influenced by the supporting ligands, but also by the ligating species present in aqueous media. Rather than a single value defined in terms of the hydride donor, a continuum of hydricity values should be considered. Being cognizant of the resulting product after hydride transfer makes direct comparisons between catalysts and conditions possible.

The hydricity scales suggest new strategies in aqueous catalysis. The synthetic chemist instinctively tunes catalysts through ligand modifications, but tuning the medium itself can also effect changes in hydricity. The present findings will guide further thermodynamic studies of PCET events in water and guide aqueous catalyst development.

\section{EXPERIMENTAL SECTION}

General Considerations. Procedures were carried out under nitrogen except where noted. All solutions containing metal hydride species were protected from ambient light to prevent excited state reactions. ${ }^{30}$ All reagents were commercially available and used without further purification. Commercial HPLC-grade water was used as a solvent, and organic solvents were dried and degassed with argon using a Pure Process Technology solvent system. Deuterated solvents were purchased from Cambridge Isotope Laboratories, Inc. Electrochemical experiments were performed on a Pine WaveNow potentiostat or Pine WaveDriver bipotentiostat controlled by Aftermath software. Details on specific electrochemical experiments are described below. Solution $\mathrm{pH}$ was recorded using an OrionStar A111 pH meter with a BeckmanCoulter, Hanna, or Hach ISFET $\mathrm{pH}$ probe. UV-vis spectra were obtained using an Ocean Optics USB2000+ spectrometer with a DTMINI-2GS deuterium/tungsten halogen light source controlled by OceanView software. 
NMR spectra were obtained on 400, 500, or $600 \mathrm{MHz}$ spectrometers. ${ }^{1} \mathrm{H}$ NMR spectra were referenced to the residual solvent signals (or dioxane or $\mathrm{NaOTs}$ as an internal standard in $\left.\mathrm{D}_{2} \mathrm{O}\right){ }^{54}$ Spectra were processed using the MestReNova software suite from Mestrelab Research S. L. The solution acidity in NMR experiments is reported as $\mathrm{pD}$, obtained by addition of +0.4 to the reading of a $\mathrm{pH}$ electrode that was calibrated using $\mathrm{H}_{2} \mathrm{O}$ standards. ${ }^{55}$

ESI-MS were obtained on a Thermo Scientific LTQ FT-ICR MS with samples introduced either through direct infusion or by LC. Inductively coupled plasma-mass spectrometry (ICP-MS, Agilent Technologies $7500 \mathrm{x}$ series) was employed to determine the precise $\mathrm{Ir}$ and $\mathrm{Ru}$ concentrations in UV-vis samples (for molar extinction coefficient determination), with the aid of a calibration curve for 10$500 \mathrm{ppb}$ Ir and Ru.

Electrochemistry. Electrochemical experiments were carried out with carbon working electrodes, platinum wire counter electrodes, and $\mathrm{Ag} / \mathrm{AgCl}(3 \mathrm{M} \mathrm{NaCl})$ reference electrode in a small glass tube fitted with a Vycor glass frit. Solutions were thoroughly degassed by sparging with nitrogen for at least $15 \mathrm{~min}$ before beginning an experiment. All potentials are reported relative to NHE, with values obtained by adding $0.21 \mathrm{~V}$ to the experimentally observed potential vs $\mathrm{Ag} / \mathrm{AgCl}^{56}$

Cyclic voltammetry experiments were carried out with a glassy carbon working electrode (polished with $0.05 \mu \mathrm{m}$ alumina powder between scans) in an undivided cell. Controlled potential electrolysis experiments were carried out with reticulated vitreous carbon (RVC) as the working electrode separated from the counter electrode and reference electrodes by a fine frit in an $\mathrm{H}$-cell.

Potentiometric experiments were performed in a custom-made three-compartment cell divided by fine frits and with a $10 \mathrm{~mm} \times 10$ $\mathrm{mm}$ Pyrex glass cuvette affixed to the central working electrode chamber (Figure S1). The solution was stirred at the base of the cuvette and by a slow bubble of $\mathrm{N}_{2}$ through the length of the cuvette to ensure sufficient mixing near the electrode. An RVC electrode was used as the working electrode for both the electrolysis and open circuit potential experiments. Reduction and oxidation of the analyte was achieved via short periods of electrolysis, and after each pulse of current, sufficient time was allowed for the solution components to come into equilibrium (typically $5-10 \mathrm{~min}$ ) as judged by an unchanging open circuit potential over $30 \mathrm{~s}$. After equilibrium was established, UV-vis spectra were recorded.

Synthesis. The complexes $[\mathrm{Cp} * \operatorname{Ir}(\mathrm{bpy})(\mathrm{Cl})][\mathrm{Cl}] \quad(\mathbf{1 C l})$, $[($ cymene $) \mathrm{Ru}($ bpy $)(\mathrm{Cl})][\mathrm{Cl}] \quad(4 \mathrm{Cl}),\left[\left(\mathrm{C}_{6} \mathrm{Me}_{6}\right) \mathrm{Ru}(\right.$ bpy $\left.)(\mathrm{Cl})\right][\mathrm{Cl}]$ $(5 \mathrm{Cl}),[\mathrm{Cp} * \operatorname{Ir}($ bpy-Me $)(\mathrm{Cl})][\mathrm{Cl}](6 \mathrm{Cl})$, and $[\mathrm{Cp} * \operatorname{Ir}($ bpy-OMe $)-$ $(\mathrm{Cl})][\mathrm{Cl}](7 \mathrm{Cl})$ were prepared following the method of Dadci et al., with final precipitation from $\mathrm{MeOH} /$ ether. $^{57}\left[\mathrm{Cp} * \mathrm{Ir}(\mathrm{Cl})_{2}\right]_{2},{ }^{58}$ $[\mathrm{Cp} * \operatorname{Ir}(\mathrm{bpy}-\mathrm{COOH})(\mathrm{Cl})][\mathrm{Cl}],{ }^{34}$ and $[\mathrm{Cp} * \operatorname{Ir}(\mathrm{bpy})(\mathrm{H})][\mathrm{OTf}]^{47}$ were prepared following literature procedures. $\left[\mathrm{Cp} * \operatorname{Ir}(\mathrm{bpy})\left(\mathrm{OH}_{2}\right)\right]\left[\mathrm{SO}_{4}\right]^{27}$ $\left(1 \mathrm{OH}_{2}\right),\left[\mathrm{Cp} * \mathrm{Ir}(\mathrm{bpy}-\mathrm{COOH})\left(\mathrm{OH}_{2}\right)\right][\mathrm{OTf}]_{2}{ }^{59}\left(2 \mathrm{OH}_{2}\right)$, and $\left[(\right.$ cymene $) \mathrm{Ru}($ bpy-COOH $\left.)\left(\mathrm{OH}_{2}\right)\right][\mathrm{OTf}]_{2}{ }^{46}\left(3 \mathrm{OH}_{2}\right)$ were prepared following literature procedures with the appropriate silver salt.

$[C p * \operatorname{lr}(b p y-C O O)(H)]^{-}(2 H)$ and $[C p * / r(b p y-C O O)]^{2-}(2)$. Electrolysis of $2 \mathrm{Cl}$ in $\mathrm{NaP}_{\mathrm{i}}, \mathrm{Na}_{2} \mathrm{SO}_{4}$, or $\mathrm{NaOH}$ electrolytes (depending on the desired use of the product) past the first reduction feature $(\sim-1.0 \mathrm{~V})$ resulted in conversion to reduced products, consistent with previously reported spectroscopic and electrochemical properties. ${ }^{30}$ The form of these products (either $2 \mathrm{H}$ or 2 ) was highly dependent on solution $\mathrm{pH}$, giving $2 \mathrm{H}$ at neutral $\mathrm{pH}, 2$ at high $\mathrm{pH}$, and a mixture in between. To confirm the identities of these reduced products, $2 \mathrm{Cl}(9.3 \mathrm{mg}, 0.014$ mmol) was reduced by excess $\mathrm{NaBH}_{4}(3.7 \mathrm{mg}, 0.98 \mathrm{mmol})$ by stirring for $30 \mathrm{~min}$ in $\mathrm{MeOH}$. Filtration and evaporation produced a dark brown film. Dissolution in neutral water provided $2 \mathrm{H}$, and dissolution in basic water provided 2. $2 \mathrm{H}:{ }^{1} \mathrm{H}$ NMR $\left(600 \mathrm{MHz}, \mathrm{D}_{2} \mathrm{O}+\right.$ dioxane $) \delta$ $8.69(\mathrm{~d}, J=5.9 \mathrm{~Hz}, 2 \mathrm{H}), 8.55(\mathrm{~s}, 2 \mathrm{H}), 7.72(\mathrm{~d}, J=5.9 \mathrm{~Hz}, 2 \mathrm{H}), 1.77$ $(\mathrm{s}, 15 \mathrm{H}),-11.90(\mathrm{~s}, 1 \mathrm{H}) . \lambda_{\text {abs, } \max }\left(\mathrm{pH} 70.1 \mathrm{M} \mathrm{NaP}_{i}\right)=428 \mathrm{~nm}(3700$ $\left.\mathrm{M}^{-1} \mathrm{~cm}^{-1}\right) .2:{ }^{1} \mathrm{H}$ NMR (400 MHz, $\mathrm{D}_{2} \mathrm{O}+$ dioxane) $\delta 8.81(\mathrm{~d}, J=7.0$ $\mathrm{Hz}, 1 \mathrm{H}), 8.42(\mathrm{~s}, 1 \mathrm{H}), 6.82(\mathrm{dd}, \mathrm{J}=6.9,2.0 \mathrm{~Hz}, 1 \mathrm{H}) .1 .80(\mathrm{~s}, 15 \mathrm{H})$. $\lambda_{\text {abs,max }}(1 \mathrm{M} \mathrm{NaOH})=292 \mathrm{~nm}\left(22000 \mathrm{M}^{-1} \mathrm{~cm}^{-1}\right), 364 \mathrm{~nm}(10800$ $\left.\mathrm{M}^{-1} \mathrm{~cm}^{-1}\right), 535 \mathrm{~nm}\left(23000 \mathrm{M}^{-1} \mathrm{~cm}^{-1}\right)$.

[(Cymene) Ru(bpy-COOH) $(\mathrm{Cl})][\mathrm{Cl}] \quad(3 \mathrm{Cl})$. Under nitrogen, $\left[(\text { cymene }) \mathrm{RuCl}_{2}\right]_{2}(50.3 \mathrm{mg}, 0.082 \mathrm{mmol})$ and bpy-COOH $(40.3$ $\mathrm{mg}, 0.165 \mathrm{mmol}$ ) were allowed to stir in $8 \mathrm{~mL} \mathrm{DMF}$ at $60^{\circ} \mathrm{C}$ for $3 \mathrm{~h}$. After filtering the solution in air to remove unreacted ligand, the DMF was removed in vacuo. The resulting film was dissolved in $\mathrm{MeOH}$, and yellow $3 \mathrm{Cl}$ (83.4 $\mathrm{mg}$, 92\% yield) precipitated from solution on addition of ether. The ${ }^{1} \mathrm{H}$ NMR spectrum matched the previously reported data. ${ }^{46}$

$\left[(\right.$ Cymene $) \mathrm{Ru}(\text { bpy-COO) }(\mathrm{H})]^{-}(3 \mathrm{H})$ and [(cymene) $\mathrm{Ru}(\text { bpy-COO) }]^{2-}$ (3). The hydride $3 \mathrm{H}$ and reduced complex 3 were prepared according to the procedures for $2 \mathrm{H}$ and 2. $3 \mathrm{H}$ : ${ }^{1} \mathrm{H}$ NMR $\left(600 \mathrm{MHz}, \mathrm{D}_{2} \mathrm{O}+\right.$ dioxane) $\delta 8.87(\mathrm{~d}, J=5.8 \mathrm{~Hz}, 2 \mathrm{H}), 8.53(\mathrm{~d}, J=1.5 \mathrm{~Hz}, 2 \mathrm{H}), 7.64(\mathrm{dd}$, $J=5.9,1.6 \mathrm{~Hz}, 2 \mathrm{H}), 5.70(\mathrm{~d}, J=6.2 \mathrm{~Hz}, 2 \mathrm{H}), 5.51(\mathrm{~d}, J=6.1 \mathrm{~Hz}, 2 \mathrm{H})$ 2.63 (sept, $J=6.9 \mathrm{~Hz}, 1 \mathrm{H}), 2.24(\mathrm{~s}, 3 \mathrm{H}), 1.07(\mathrm{~d}, J=6.9 \mathrm{~Hz}, 6 \mathrm{H})$, $-6.21(\mathrm{~s}, 1 \mathrm{H}) \cdot \lambda_{\text {abs,max }}\left(\mathrm{pH} 70.1 \mathrm{M} \mathrm{NaP}_{i}\right)=295 \mathrm{~nm}\left(20800 \mathrm{M}^{-1}\right.$ $\left.\mathrm{cm}^{-1}\right), 434 \mathrm{~nm}\left(5500 \mathrm{M}^{-1} \mathrm{~cm}^{-1}\right) .3:{ }^{1} \mathrm{H}$ NMR $\left(600 \mathrm{MHz}, \mathrm{D}_{2} \mathrm{O}+\right.$ dioxane) $\delta 8.82(\mathrm{~d}, J=6.8 \mathrm{~Hz}, 2 \mathrm{H}), 8.37(\mathrm{~s}, 2 \mathrm{H}), 7.12(\mathrm{~d}, J=6.7 \mathrm{~Hz}$, $2 \mathrm{H}), 4.84(\mathrm{~d}, J=5.5 \mathrm{~Hz}, 2 \mathrm{H}), 4.81(\mathrm{~d}, J=5.7 \mathrm{~Hz}, 2 \mathrm{H}), 2.32$ (sept, $J=$ $7.7 \mathrm{~Hz}, 1 \mathrm{H}), 1.85(\mathrm{~s}, 3 \mathrm{H}), 0.86(\mathrm{~d}, J=6.7 \mathrm{~Hz}, 6 \mathrm{H}) . \lambda_{\mathrm{abs}, \max }(1 \mathrm{M}$ $\mathrm{NaOH})=298 \mathrm{~nm}\left(22600 \mathrm{M}^{-1} \mathrm{~cm}^{-1}\right), 374 \mathrm{~nm}\left(13500 \mathrm{M}^{-1} \mathrm{~cm}^{-1}\right)$ $506 \mathrm{~nm}\left(17600 \mathrm{M}^{-1} \mathrm{~cm}^{-1}\right), 610 \mathrm{~nm}\left(14400 \mathrm{M}^{-1} \mathrm{~cm}^{-1}\right)$.

$C p * \operatorname{lr}(b p y)(1)$. In a nitrogen filled glovebox, $[\mathrm{Cp} * \operatorname{Ir}(\mathrm{bpy})(\mathrm{Cl})][\mathrm{Cl}]$ $(15.5 \mathrm{mg}, 0.028 \mathrm{mmol})$ and excess $\mathrm{NaBH}_{4}(8.5 \mathrm{mg}, 0.223 \mathrm{mmol})$ were allowed to stir in $2 \mathrm{~mL}$ of $1 \mathrm{M} \mathrm{NaOH}$. Dark purple solids quickly formed. After letting stir for $4 \mathrm{~h}$, the solid was filtered off, washed $3 \times$ with water, collected in benzene, and evaporated to dryness, yielding 1 (13.3 mg, 98\% yield). The ${ }^{1} \mathrm{H}$ NMR spectrum of 1 prepared in this way matched previously reported data. ${ }^{60}$

$[C p * \operatorname{lr}(b p y)(H)][C l](1 H)$. To a stirring solution of $1(13.3 \mathrm{mg}, 0.028$ $\mathrm{mmol})$ in ether, a dilute solution of $\mathrm{HCl} \cdot \mathrm{Et}_{2} \mathrm{O}(40 \mathrm{mM})$ was added dropwise until a change from a dark purple solution to bright yellow solids was observed. Typically $1-1.5$ equiv of $\mathrm{HCl}$ was added with the excess acid immediately pumped off after completion of the addition. Samples of hydride prepared in this way typically contained small amounts $(<5 \%)$ of $[\mathrm{Cp} * \operatorname{Ir}(\mathrm{bpy})(\mathrm{Cl})][\mathrm{Cl}]$ (formed by protonation of hydride releasing $\mathrm{H}_{2}$ ), and the ${ }^{1} \mathrm{H}$ NMR spectrum is consistent with previously reported $[\mathrm{Cp} * \operatorname{Ir}(\mathrm{bpy})(\mathrm{H})]^{+} .{ }^{30}$

(Cymene)Ru(bpy) (4). Deep purple 4 was prepared in quantitative yield from the chloride salt of $4 \mathrm{Cl}$, according to the procedure used in the synthesis of 1 . The ${ }^{1} \mathrm{H}$ NMR spectrum matched the previously reported data. $^{61}$

[(Cymene)Ru(bpy)(H)][Cl] (4H). The chloride salt of $4 \mathrm{H}$ was prepared from 4 , according to the procedure used in the synthesis of the chloride salt of $1 \mathrm{H} .{ }^{1} \mathrm{H}$ NMR $\left(600 \mathrm{MHz}, \mathrm{D}_{2} \mathrm{O}+\right.$ dioxane $) \delta 8.78$ $(\mathrm{d}, J=4.1 \mathrm{~Hz}, 2 \mathrm{H}), 8.09(\mathrm{~d}, J=8.2 \mathrm{~Hz}, 2 \mathrm{H}), 7.87(\mathrm{t}, J=7.8 \mathrm{~Hz}, 2 \mathrm{H})$, $7.32(\mathrm{dd}, J=7.3,5.8 \mathrm{~Hz}, 2 \mathrm{H}), 5.56(\mathrm{~d}, J=6.0 \mathrm{~Hz}, 2 \mathrm{H}), 5.36(\mathrm{~d}, J=6.0$ $\mathrm{Hz}, 2 \mathrm{H}), 2.53(\mathrm{sept}, J=7.1 \mathrm{~Hz}, 1 \mathrm{H}), 2.10(\mathrm{~s}, 3 \mathrm{H}), 0.99(\mathrm{~d}, J=6.9 \mathrm{~Hz}$, $6 \mathrm{H}),-6.32(\mathrm{~s}, 1 \mathrm{H})$.

$\left(\mathrm{C}_{6} M e_{6}\right) R u(b p y)$ (5). Deep purple 5 was prepared in quantitative yield from the chloride salt of $5 \mathrm{Cl}$, according to the procedure used in the synthesis of 1 . The ${ }^{1} \mathrm{H}$ NMR spectrum matched the previously reported data. ${ }^{61}$

$\left[\left(\mathrm{C}_{6} \mathrm{Me} \mathrm{e}_{6}\right) \mathrm{Ru}(\mathrm{bpy})(\mathrm{H})\right][\mathrm{Cl}](5 \mathrm{H})$. The chloride salt of $5 \mathrm{H}$ was prepared from 5, according to the procedure used in the synthesis of the chloride salt of $1 \mathrm{H}$. The ${ }^{1} \mathrm{H}$ NMR spectrum is consistent with the reported spectrum for the triflate salt of $5 \mathrm{H}$ in water. ${ }^{62}$

$C p * I r(b p y-M e)$ (6). In a nitrogen filled glovebox, [Cp* $\operatorname{Ir}(\mathrm{bpy}-$ $\mathrm{Me})(\mathrm{Cl})][\mathrm{Cl}](5.8 \mathrm{mg}, 0.010 \mathrm{mmol})$ and excess $\mathrm{NaBH}_{4}(5.1 \mathrm{mg}$, $0.135 \mathrm{mmol}$ ) were allowed to stir in $2 \mathrm{~mL}$ of $5 \mathrm{M} \mathrm{NaOH}$, and a dark violet solid quickly formed. After letting stir for $4 \mathrm{~h}$, the solid was extracted into $\mathrm{C}_{6} \mathrm{H}_{6}$, dried over $\mathrm{MgSO}_{4}$, and evaporated to dryness, yielding 6 in quantitative yield. ${ }^{1} \mathrm{H}$ NMR $\left(600 \mathrm{MHz}, \mathrm{C}_{6} \mathrm{D}_{6}\right) \delta 8.91(\mathrm{~d}$, $J=6.8 \mathrm{~Hz}, 2 \mathrm{H}), 7.44(\mathrm{~s}, 2 \mathrm{H}), 6.06(\mathrm{dd}, J=6.8,2.1 \mathrm{~Hz}, 2 \mathrm{H}), 2.02(\mathrm{~s}$, $6 \mathrm{H}), 1.82(\mathrm{~s}, 15 \mathrm{H}) .{ }^{13} \mathrm{C}$ NMR $\left(151 \mathrm{MHz}, \mathrm{C}_{6} \mathrm{D}_{6}\right) \delta 148.20,141.06$, $127.59,122.82,117.92,83.32,21.44,10.24 . \lambda_{\mathrm{abs}, \max }\left(\mathrm{C}_{6} \mathrm{H}_{6}\right)=499,641$, $687 \mathrm{~nm}$.

$[C p * \operatorname{lr}(b p y-M e)(H)][C l](6 \mathrm{H})$. The bright yellow chloride salt of $6 \mathrm{H}$ was prepared from 6 , according to the procedure used in the synthesis of the chloride salt of $1 \mathrm{H} .{ }^{1} \mathrm{H}$ NMR $\left(600 \mathrm{MHz}, \mathrm{D}_{2} \mathrm{O}+\right.$ dioxane $) \delta 8.55$ $(\mathrm{d}, J=5.8 \mathrm{~Hz}, 2 \mathrm{H}), 7.91(\mathrm{~s}, 2 \mathrm{H}), 7.32(\mathrm{~d}, J=6.0 \mathrm{~Hz}, 2 \mathrm{H}), 2.51(\mathrm{~s}$, $6 \mathrm{H}), 1.75(\mathrm{~s}, 15 \mathrm{H}),-11.51(\mathrm{~s}, 1 \mathrm{H}) \cdot \lambda_{\mathrm{abs}, \max }\left(\mathrm{pH} 70.1 \mathrm{M} \mathrm{NaP}_{i}\right)=394$ $\mathrm{nm}\left(2900 \mathrm{M}^{-1} \cdot \mathrm{cm}^{-1}\right)$. 
$\left[C P^{*} / r(b p y-O M e)(H)\right]^{+}(7 H)$. Controlled potential electrolysis of $[\mathrm{Cp} * \operatorname{Ir}($ bpy-OMe $)(\mathrm{Cl})][\mathrm{Cl}]$ at $-1.0 \mathrm{~V}$ in $0.1 \mathrm{M} \mathrm{pD} 7 \mathrm{NaP}_{i}$ resulted in clean formation of $[\mathrm{Cp} * \operatorname{Ir}(\mathrm{bpy}-\mathrm{OMe})(\mathrm{H})]^{+}$, consistent with previously reported spectroscopic and electrochemical properties. ${ }^{30}{ }^{1} \mathrm{H}$ NMR $\left(600 \mathrm{MHz}, \mathrm{D}_{2} \mathrm{O}+\right.$ dioxane $) \delta 8.49(\mathrm{~d}, J=6.5 \mathrm{~Hz}, 2 \mathrm{H}), 7.44(\mathrm{~s}$, $2 \mathrm{H}), 7.06(\mathrm{dd}, J=6.6,2.8 \mathrm{~Hz}, 2 \mathrm{H}), 3.98(\mathrm{~s}, 6 \mathrm{H}), 1.75(\mathrm{~s}, 15 \mathrm{H})$, $-11.23(\mathrm{~s}, 1 \mathrm{H})$

Cp*Ir(bpy-COOMe) (8). In a nitrogen filled glovebox, $8.1 \mathrm{mg}(0.012$ $\mathrm{mmol})[\mathrm{Cp} * \operatorname{Ir}($ bpy-COOMe $)(\mathrm{Cl})][\mathrm{Cl}]$ and $4.7 \mathrm{~g}(0.069 \mathrm{mmol})$ $\mathrm{NaO}_{2} \mathrm{CH}$ were stirred in $2 \mathrm{~mL} \mathrm{pH} 70.1 \mathrm{M} \mathrm{NaP}_{i}$. While stirring for $4 \mathrm{~h}$, a royal purple solid precipitated from solution. The solution was filtered, and the solids were washed $3 \times$ with water, collected by dissolving in benzene, and evaporated under vacuum to yield 8 (3.4 mg, $47 \%$ yield). ${ }^{1} \mathrm{H}$ NMR (600 MHz, $\left.\mathrm{C}_{6} \mathrm{D}_{6}\right) \delta 8.78(\mathrm{~d}, J=7.0 \mathrm{~Hz}$, $1 \mathrm{H}), 8.69(\mathrm{~d}, J=2.1 \mathrm{~Hz}, 1 \mathrm{H}), 7.20(\mathrm{dd}, J=7.0,2.0 \mathrm{~Hz}, 1 \mathrm{H}), 3.52(\mathrm{~s}$, $2 \mathrm{H}), 1.55(\mathrm{~s}, 6 \mathrm{H}) .{ }^{13} \mathrm{C} \mathrm{NMR}\left(151 \mathrm{MHz}, \mathrm{C}_{6} \mathrm{D} 6\right) \delta 166.76,147.22$, $142.02,125.72,120.11,115.04,85.57,51.76,9.68 . \lambda_{\text {abs,max }}\left(\mathrm{C}_{6} \mathrm{H}_{6}\right)=$ $328,389,552 \mathrm{~nm}$.

$[C p * \operatorname{lr}(b p y-C O O M e)(H)][C l](8 H)$. The scarlet chloride salt of $8 \mathrm{H}$ was prepared from 8 , according to the procedure used in the synthesis of the chloride salt of $1 \mathrm{H} .{ }^{1} \mathrm{H}$ NMR $\left(600 \mathrm{MHz}, \mathrm{D}_{2} \mathrm{O}+\right.$ dioxane $) \delta 8.89$ $(\mathrm{d}, J=5.9 \mathrm{~Hz}, 2 \mathrm{H}), 8.69(\mathrm{~s}, 2 \mathrm{H}), 7.92(\mathrm{~d}, J=5.9 \mathrm{~Hz}, 2 \mathrm{H}), 4.10(\mathrm{~s}$, $6 \mathrm{H}), 1.80(\mathrm{~s}, 15 \mathrm{H}),-12.28(\mathrm{~s}, 1 \mathrm{H}) .{ }^{13} \mathrm{C}$ NMR $\left(151 \mathrm{MHz}, \mathrm{D}_{2} \mathrm{O}\right) \delta$ $165.82,155.95,153.00,138.06,126.69,123.19,92.70,54.39,8.94$. $\lambda_{\text {abs, max }}\left(\mathrm{pH} 30.1 \mathrm{M} \mathrm{NaP}_{i}\right)=388 \mathrm{~nm}\left(4200 \mathrm{M}^{-1} \cdot \mathrm{cm}^{-1}\right), 451 \mathrm{~nm}(4300$ $\left.\mathrm{M}^{-1} \cdot \mathrm{cm}^{-1}\right), 481 \mathrm{~nm}\left(4400 \mathrm{M}^{-1} \cdot \mathrm{cm}^{-1}\right)$.

Thermodynamic Measurements. Hydride Equilibrations. In a typical equilibration experiment to determine relative hydricity according to Figure $1 \mathrm{~B}, 19.3 \mathrm{mg}$ of $2 \mathrm{Cl}$ was dissolved by sonication in $2 \mathrm{~mL}$ of $\mathrm{pD} 70.1 \mathrm{NaP}_{i}$, added to the working electrode compartment of an $\mathrm{H}$-cell, and degassed for $15 \mathrm{~min}$. The counter electrode compartment was charged with $2 \mathrm{~mL}$ pD $70.1 \mathrm{NaP}_{i}$. The solution was electrolyzed at $-1.0 \mathrm{~V}$ for $6 \mathrm{~h}$, transferred to a $\mathrm{N}_{2}$ purged bomb flask, and brought into a glovebox. Different volumes of the electrolyzed solution $(100,200$, and $300 \mu \mathrm{L}$ ) were added to three samples containing $3.5 \mathrm{mmol} 1 \mathrm{Cl}$ and dioxane, and the total volume was brought to $500 \mu \mathrm{L}$. Samples were monitored by ${ }^{1} \mathrm{H}$ NMR, and equilibrium of the experimental samples was quickly achieved; though the samples were monitored over $25 \mathrm{~h}$ by ${ }^{1} \mathrm{H}$ NMR, equilibrium $\left(K_{\mathrm{eq}}\right.$ $=0.35)$ was established by the first time point, giving $\Delta \Delta G_{\mathrm{H}^{-}}^{\circ}=0.6 \pm$ $0.1 \mathrm{kcal} \cdot \mathrm{mol}^{-1}$.

Alternatively, following protonation with $\mathrm{HCl} \cdot \mathrm{Et}_{2} \mathrm{O}$, the solid hydride was extracted into the NMR solvent (either pD $70.1 \mathrm{M}$ $\mathrm{NaP}_{i}$ or pD $4.320 \mathrm{mM} \mathrm{NaOAc}$ with dioxane internal standards), filtered to remove any residual $\mathrm{Cp} * \operatorname{Ir}(\mathrm{bpy}-\mathrm{X})$ or (arene) $\mathrm{Ru}(\mathrm{bpy}-\mathrm{X})$, and combined with a hydride acceptor. Equilibration was followed by ${ }^{1} \mathrm{H}$ NMR. In a representative experiment, $2.0 \mathrm{mg}$ of [Cp* $\operatorname{Ir}(\mathrm{bpy})-$ (H) $][\mathrm{Cl}](0.004 \mathrm{mmol})$ was dissolved in $490 \mu \mathrm{L}$ of pD $70.1 \mathrm{M} \mathrm{NaP}_{i}$ with $10 \mu \mathrm{L}$ of $0.5 \mathrm{M}$ dioxane as an internal standard. After confirming the purity of the hydride sample by ${ }^{1} \mathrm{H}$ NMR, $2.1 \mathrm{mg}$ [Cp* $\operatorname{Ir}($ bpy-Me) $(\mathrm{Cl})][\mathrm{Cl}](0.004 \mathrm{mmol})$ was added to the NMR tube as a solid. $\Delta \Delta G^{\circ}{ }_{H^{-}}$was determined to be $0.4 \pm 0.1 \mathrm{kcal} \cdot \mathrm{mol}^{-1}$.

Aquo-Chloride Association Equilibria. For each species, a series solutions of a known concentration of chloride were prepared in $\mathrm{pD} 7$ $\mathrm{NaP}_{i}$ and monitored by NMR to ensure that the aquo, phosphate, and chloride species were in equilibrium. For example, In air, a $5.5 \mathrm{mM}$ solution of $\left[\mathrm{Cp} * \operatorname{Ir}(\mathrm{bpy}-\mathrm{COOH})\left(\mathrm{OH}_{2}\right)\right][\mathrm{OTf}]_{2}$ in $50 \mathrm{mM}$ pD $7 \mathrm{NaP}_{i}$ with a dioxane internal standard was split between six samples each containing dry $\mathrm{NaCl}$ to produce final solutions with $\left[\mathrm{Cl}^{-}\right]$from 0 to 18 $\mathrm{mM}$. The samples were monitored by ${ }^{1} \mathrm{H}$ NMR over $24 \mathrm{~h}$ to ensure that equilibrium had been established between $[\mathrm{Cp} * \operatorname{Ir}(\mathrm{bpy}-\mathrm{COO})$ $\left.\left(\mathrm{OH}_{2}\right)\right]^{0},\left[\mathrm{Cl}^{-}\right]$and $[\mathrm{Cp} * \mathrm{Ir}(\text { bpy-COO})(\mathrm{Cl})]^{-}$. The initial $\left[\mathrm{Cl}^{-}\right]$left from the halide abstraction with AgOTf was fit by minimizing the variance of $\Delta G$ of the $0 \mathrm{mM} \mathrm{NaCl}$ added sample with that of the remaining five samples. The free energy of the ligand exchange was found to be $-4.4 \pm 0.2 \mathrm{kcal} \cdot \mathrm{mol}^{-1}$. The relative aquo-phosphate association free energy was determined similarly with solutions of increasing total $\left[\mathrm{P}_{i}\right]$ at $\mathrm{pD} 7$.

\section{ASSOCIATED CONTENT}

\section{Supporting Information}

The Supporting Information is available free of charge on the ACS Publications website at DOI: 10.1021/jacs.5b12363.

Full synthetic and experimental details, ${ }^{1} \mathrm{H}$ and ${ }^{13} \mathrm{C}$ NMR spectra, details of thermodynamic calculations (PDF)

\section{AUTHOR INFORMATION}

\section{Corresponding Author}

*ajmm@email.unc.edu

\section{Notes}

The authors declare no competing financial interest.

\section{ACKNOWLEDGMENTS}

The authors gratefully acknowledge funding from NSF Center for Enabling New Technologies through Catalysis (CENTC), CHE-1205189, the University of North Carolina at Chapel Hill, and the Royster Society of Fellows (C.L.P.). We thank T. P. Brewster and K. I. Goldberg for donating complex $8 \mathrm{Cl}$, J. M. Mayer and O. N. L. Finster for their participation in helpful discussions, and P. H. Cable for his assistance with analytical facilities provided by the UNC Biomarker Mass Spectrometry Facility, supported in part by a grant from the National Institute of Environmental Health Sciences (P30ES010126).

\section{REFERENCES}

(1) Vincent, K. A.; Parkin, A.; Armstrong, F. A. Chem. Rev. 2007, 107, 4366-4413.

(2) Dobbek, H.; Svetlitchnyi, V.; Gremer, L.; Huber, R.; Meyer, O. Science 2001, 293, 1281-1285.

(3) Gray, H. B. Nat. Chem. 2009, 1, 112-112.

(4) Thoi, V. S.; Sun, Y.; Long, J. R.; Chang, C. J. Chem. Soc. Rev. 2013, 42, 2388-2400.

(5) McDaniel, N. D.; Bernhard, S. Dalton Trans. 2010, 39, 1002110030.

(6) Appel, A. M.; Bercaw, J. E.; Bocarsly, A. B.; Dobbek, H.; DuBois, D. L.; Dupuis, M.; Ferry, J. G.; Fujita, E.; Hille, R.; Kenis, P. J. A.; Kerfeld, C. A.; Morris, R. H.; Peden, C. H. F.; Portis, A. R.; Ragsdale, S. W.; Rauchfuss, T. B.; Reek, J. N. H.; Seefeldt, L. C.; Thauer, R. K.; Waldrop, G. L. Chem. Rev. 2013, 113, 6621-6658.

(7) Aqueous-Phase Organometallic Catalysis, 2nd ed.; Cornils, B., Herrmann, W. A., Eds.; Wiley-VCH: Weinheim, 2004.

(8) Joó, F. Acc. Chem. Res. 2002, 35, 738-745.

(9) Volbeda, A.; Charon, M.-H.; Piras, C.; Hatchikian, E. C.; Frey, M.; Fontecilla-Camps, J. C. Nature 1995, 373, 580-587.

(10) Peters, J. W.; Lanzilotta, W. N.; Lemon, B. J.; Seefeldt, L. C. Science 1998, 282, 1853-1858.

(11) Han, Z.; Eisenberg, R. Acc. Chem. Res. 2014, 47, 2537-2544.

(12) Warren, J. J.; Tronic, T. A.; Mayer, J. M. Chem. Rev. 2010, 110, 6961-7001.

(13) Bourrez, M.; Steinmetz, R.; Ott, S.; Gloaguen, F.; Hammarström, L. Nat. Chem. 2015, 7, 140-145.

(14) DuBois, D. L.; Berning, D. E. Appl. Organomet. Chem. 2000, 14, $860-862$.

(15) Rakowski DuBois, M.; DuBois, D. L. Chem. Soc. Rev. 2009, 38, $62-72$.

(16) Bullock, R. M.; Appel, A. M.; Helm, M. L. Chem. Commun. 2014, 50, 3125-3143.

(17) Helm, M. L.; Stewart, M. P.; Bullock, R. M.; Rakowski DuBois, M.; Dubois, D. L. Science 2011, 333, 863-866.

(18) Rodriguez-Maciá, P.; Dutta, A.; Lubitz, W.; Shaw, W. J.; Rüdiger, O. Angew. Chem., Int. Ed. 2015, 54, 12303-12307.

(19) Connelly, S. J.; Wiedner, E. S.; Appel, A. M. Dalton Trans. 2015, 44, 5933-5938. 
(20) Creutz, C.; Chou, M. H. J. Am. Chem. Soc. 2007, 129, 1010810109.

(21) Creutz, C.; Chou, M. H. J. Am. Chem. Soc. 2009, 131, 27942795.

(22) Taheri, A.; Thompson, E. J.; Fettinger, J. C.; Berben, L. A. ACS Catal. 2015, 5, 7140-7151.

(23) Tsay, C.; Livesay, B. N.; Ruelas, S.; Yang, J. Y. J. Am. Chem. Soc. 2015, 137, 14114-14121.

(24) See the Supporting Information for full details.

(25) Berning, D. E.; Noll, B. C.; DuBois, D. L. J. Am. Chem. Soc. 1999, 121, 11432-11447.

(26) Brewster, T. P.; Miller, A. J. M.; Heinekey, D. M.; Goldberg, K. I. J. Am. Chem. Soc. 2013, 135, 16022-16025.

(27) Miller, A. J. M.; Heinekey, D. M.; Mayer, J. M.; Goldberg, K. I. Angew. Chem., Int. Ed. 2013, 52, 3981-3984.

(28) Hull, J. F.; Himeda, Y.; Wang, W.-H.; Hashiguchi, B.; Periana, R.; Szalda, D. J.; Muckerman, J. T.; Fujita, E. Nat. Chem. 2012, 4, 383388.

(29) Fukuzumi, S.; Kobayashi, T.; Suenobu, T. Angew. Chem., Int. Ed. 2011, 50, 728-731.

(30) Pitman, C. L.; Miller, A. J. M. ACS Catal. 2014, 4, 2727-2733.

(31) Himeda, Y. Green Chem. 2009, 11, 2018-2022.

(32) Ogo, S.; Kabe, R.; Hayashi, H.; Harada, R.; Fukuzumi, S. Dalton

Trans. 2006, 39, 4657-4663.

(33) Taheri, A.; Berben, L. A. Inorg. Chem. 2016, 55, 378-385.

(34) Ziessel, R. J. Am. Chem. Soc. 1993, 115, 118-127.

(35) Dutton, L. P. Methods Enzymol. 1978, 54, 411-435.

(36) Pugh, J. R.; Meyer, T. J. J. Am. Chem. Soc. 1992, 114, 37843792.

(37) Seifriz, I.; Konzen, M.; Paula, M. M. S.; Gonçalves, N. S.; Spoganickz, B.; Creczynski-Pasa, T. B.; Bonetti, V. R.; Beirith, A.; Calixto, J. B.; Franco, C. V. J. Inorg. Biochem. 1999, 76, 153-163.

(38) Ardo, S.; Achey, D.; Morris, A. J.; Abrahamsson, M.; Meyer, G. J. J. Am. Chem. Soc. 2011, 133, 16572-16580.

(39) Ciancanelli, R.; Noll, B. C.; DuBois, D. L.; Rakowski DuBois, M. J. Am. Chem. Soc. 2002, 124, 2984-2992.

(40) Wilson, A. D.; Miller, A. J. M.; DuBois, D. L.; Labinger, J. A.; Bercaw, J. E. Inorg. Chem. 2010, 49, 3918-3926.

(41) Matsubara, Y.; Fujita, E.; Doherty, M. D.; Muckerman, J. T.; Creutz, C. J. Am. Chem. Soc. 2012, 134, 15743-15757.

(42) Hu, Y.; Norton, J. R. J. Am. Chem. Soc. 2014, 136, 5938-5948.

(43) Kolthoff, I. M. Anal. Chem. 1974, 46, 1992-2003.

(44) Five-coordinate $d^{8}$ transition metal hydrides have been a focus of studies in $\mathrm{MeCN}$. Solvent ligation is minimized in these cases because the product of hydride transfer is $\mathrm{d}^{8}$ square planar. See ref 15 . (45) Robertson, A.; Matsumoto, T.; Ogo, S. Dalton Trans. 2011, 40, 10304-10310.

(46) de Respinis, M.; Joya, K. S.; De Groot, H. J. M.; D’Souza, F.; Smith, W. A.; van de Krol, R.; Dam, B. J. Phys. Chem. C 2015, 119, $7275-7281$.

(47) Barrett, S. M.; Pitman, C. L.; Walden, A. G.; Miller, A. J. M. J. Am. Chem. Soc. 2014, 136, 14718-14721.

(48) Ellis, W. W.; Miedaner, A.; Curtis, C. J.; Gibson, D. H.; DuBois,

D. L. J. Am. Chem. Soc. 2002, 124, 1926-1932.

(49) Bhagan, S.; Wayland, B. B. Inorg. Chem. 2011, 50, 1101111020 .

(50) Curtis, C. J.; Miedaner, A.; Ellis, W. W.; DuBois, D. L. J. Am. Chem. Soc. 2002, 124, 1918-1925.

(51) Hansch, C.; Leo, A.; Taft, R. W. Chem. Rev. 1991, 91, 165-195.

(52) Kanan, M. W.; Nocera, D. G. Science 2008, 321, 1072-1075.

(53) Karunadasa, H. I.; Chang, C. J.; Long, J. R. Nature 2010, 464, 1329-1333.

(54) Fulmer, G. R.; Miller, A. J. M.; Sherden, N. H.; Gottlieb, H. E.; Nudelman, A.; Stoltz, B. M.; Bercaw, J. E.; Goldberg, K. I. Organometallics 2010, 29, 2176-2179.

(55) Glasoe, P. K.; Long, F. A. J. Phys. Chem. 1960, 64, 188-190.

(56) Handbook of Electrochemistry; Zoski, C. G., Ed.; Elsevier: Amsterdam, 2007.
(57) Dadci, L.; Elias, H.; Frey, U.; Hoernig, A.; Koelle, U.; Merbach, A. E.; Paulus, H.; Schneider, J. S. Inorg. Chem. 1995, 34, 306-315.

(58) White, C.; Yates, A.; Maitlis, P. M. Inorg. Synth. 1992, 29, 228234.

(59) Joya, K. S.; Subbaiyan, N. K.; D’Souza, F.; de Groot, H. J. M. Angew. Chem., Int. Ed. 2012, 51, 9601-9605.

(60) Ladwig, M.; Kaim, W. J. Organomet. Chem. 1992, 439, 79-90.

(61) Kaim, W.; Reinhardt, R.; Sieger, M. Inorg. Chem. 1994, 33, 4453-4459.

(62) Ogo, S.; Uehara, K.; Abura, T.; Watanabe, Y.; Fukuzumi, S. Organometallics 2004, 23, 3047-3052. 